\title{
Impact of the International Trade on the EU Clothing Industry Carbon Emissions
}

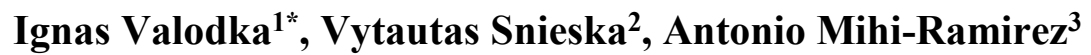 \\ ${ }^{1,2}$ Kaunas University of Technology \\ Gedimino 50-227, LT-44239 Kaunas, Lithuania \\ E-mail.ignas.valodka@ktu.edu; vytautas.snieska@ktu.lt \\ ${ }^{*}$ Corresponding author
}

${ }^{3}$ Faculty of Economics and Management, Granada University

Campus Cartuja, 18071, Granada, Spain, 18071

E-mail.amihi@ugr.es

cross'ref $^{\text {http://dx.doi.org/10.5755/j01.ee.31.3.25012 }}$

Globalization and international trade has strongly affected world's economy in the recent decades. The importance of emissions loads distribution between countries participating in the supply chains is steadily growing. In the highly fragmented global supply chain structure, with the consumption and production separated geographically and politically, it is difficult to capture the distribution of carbon emission burden within the global production processes. Several recent scientific studies have emphasized that CO2 emissions embodied in international trade processes should be addressed. The CO2 emissions up to now are mostly evaluated on the base of domestic emission accounts. To address this research gap, our study applies multi-regional input-output (MRIO) method for the estimation of the CO2 emissions embodied in the EU clothing imports. The study evaluates carbon emissions of the EU clothing imports and provides suggestions for companies and policy makers. Our results show, that the EU has not reduced CO2 emissions but instead has outsourced them. MRIO and triangulation methods were used to evaluate the EU clothing sector embodied carbon emissions in imports from 2000 to 2016. CO2 emission reduction goal can be achieved by implementing the proposed consumption based emission accounting framework additionally to the country's emission inventory. Our results may help businesses and policy makers to establish more efficient strategies towards the EU's carbon emissions.

Keywords: Environmental Sustainability; CO2 Emission; International Trade; Globalization; Textile and Clothing Sector; EU.

\section{Introduction}

Inefficient economic growth in the last decades increased the pressure on the environment and has negatively affected global climate change (IPCC, 2018). Sustainability refers to achieving a good life for all people within ecological limits of a finite planet (Jackson, 2011). Studies agree that the main drivers influencing environmental impacts are globalization, and consumption pattern changes in developed countries (Simas, Golsteijn, Huijbregts, Wood, \& Hertwich; Xu \& Dietzenbacher, 2014). Economically developed countries with affluent consumer's lifestyles, have environmental impacts on the macroeconomic structures (Lenzen, Moran, Kanemoto, Foran, Lobefaro et al., 2012). The number of studies, analysing $\mathrm{CO} 2$ emissions, outsourced from developed to developing countries, are increasing, and more and more studies find that globalization and international trade development has led to the shift of pollution into developing countries, which use heavy industry to accelerate their growth (Davis, Peters \& Caldeira, 2011). Moreover, energy intensive industries can move the production into different countries with lower restrictions and energy costs and then export the production to more restricted countries. In this way emissions can be reduced in one country while directly increased in another one. This issue in the scientific literature is called a "carbon leakage" problem.
There is more and more scientific research addressing "carbon leakage" problem and proposing consumption based method as a solution for $\mathrm{CO} 2$ emission mitigation (Afionis, Sakai, Scott, Barrett \& Gouldson, 2017; Fernandez-Amador, Francois, Oberdabernig, \& Tomberger, 2017; Davis \& Caldeira 2010; Davis et al., 2011; Liu, 2015; Steininger, Lininger, Meyer, Munoz, \& Schinko, 2015). Until now, many countries follow traditional trade accounting determined by the Intergovernmental Panel on Climate Change (IPCC). The consumption-based approach in scientific literature was used applying the Sustainable Development Goals (2015) developed by the United Nations (UN). The EU has developed the Sustainable Development Goals in the 2030 UN Agenda, to create lowcarbon consumption and production (EC, 2016). China states that producer is not the only one responsible for the emissions, and consumers should take their responsibility (Leggett, 2011). According to $\mathrm{Xu}, \mathrm{Mu}, \&$ Wang (2017), the usage of traditional emission accounting statistics, which is based only on territorial emissions, might lead to significant miscalculations. Previous studies in the scientific literature haves addressed the problem of increasing global emissions in exports (Andrew, Davis, \& Peters, 2013; Caldeira \& Davis, 2011; Hertwich \& Peters, 2009; Nakano, Okamura, Sakurai, Suzuki, Tojo et al., 2009; Peters, Marland, Le Que, Boden, Canadell et al., 2011). Studies have used consumption-based accounting method to account all 
Ignas Valodka, Vytautas Snieska, Antonio Mihi-Ramirez. Impact of the International Trade on the EU Clothing Industry...

emissions from international supply chains in global economy and have employed Global MRIO models for estimating emissions embodied in trade (Davis, Peters \& Caldeira 2011; Deng \& Xu 2017; Peters, 2008; Wiedmann, 2009). Input-output tables are highly detailed as they are extended with data by sector which enables carbon emission calculations within countries (Tukker, Huppes, Guinée, Heijungs, Koning et al., 2006). To strongly contribute to the problem of environmental impacts in consumption, the key approach for embodied environmental impacts assessment is consumption based approach method (Hamilton, Ivanova, Stadler, Merciai, Schmidt et al., 2018; Wood, Stadler, Simas, Bulavskaya, Giljum et al., 2018). Feng, Davis, Sun, Li, Guan et al. (2013) estimated that in 2005 around $30 \%$ of $\mathrm{CO} 2$ emissions were due to export production. Wiedmann, Wood, Lenzen, Minx, Guan et al. (2008) found that between 1992 and 2004, the UK's emissions have actually increased by $12 \%$, instead of decreasing by $5 \%$ as it is showed in its domestic emission inventory. Besides, country's growing demand was supplied by highly intensive carbon emission imports. Davis \& Caldeira (2010) found that $23 \%$ of carbon emission flows worldwide were embodied in exports from developing countries, as China, to developed countries.

The EU imports create higher environmental pollution implications than exports, emphasizing environmental impacts outside the EU boundaries related to the EU imported goods (Corrado, 2020). Many studies (Munksgaard, Minx, Christofferson, Pade, \& Suh 2007; Wilting \& Vringer 2007; Lenzen, Pade, \& Munksgaard, 2004) have criticized United Nations Framework Convention on Climate Change (UNFCCC) due to its usage of production based accounting and suggest the implementation of consumption based method into the national emission inventory. According to Fezzigna (2019), consumption based emission accountability implementation is very important achieving carbon emission mitigation goals and helps estimate the emissions assigned to the final consumer. However, as it is shown in Intergovernmental Panel on Climate Change (IPCC) criteria, consuming countries don't take the responsibility for the emissions emitted by exporting countries. The MRIO method is the appropriate instrument for the estimation of consumption based carbon emissions and other environmental impacts (Ali, 2017). MRIO is recognized as the right method for the estimation of environmental implications caused by economic activities from the final consumer perspective (Peters, 2008; Wiedmann, 2009). Moreover, recent studies confirm that MRIO method is an appropriate tool for calculating emission transfers embodied in trade between different economies (Duan \& Jiang, 2018; Su \& Ang, 2014; Sun, Li, Qiao, \& Zhang, 2017). Several studies employed MRIO method to study emissions in international trade and found large amounts of involved carbon emissions transfers in trade (Zhong, Jiang \& Zhou, 2018; Zhu, Shi, Wu, Wu, \& Xiong, 2018). Liu (2016) applied input-output method in his research and found large amounts of carbon emissions embodied in China's exports.

There are two key methods in the scientific literature to measure emissions embodied in trade, namely, Life Cycle Analysis (LCA) and input-output method. However, LCA is more useful in the analysis of microscopic quantification and requires data integration which limits the use of LCA methodology, while input-output method properly reflects dependencies between sectors and products as its data requirement is low. However, several studies mention some limitations regarding the MRIO framework due to various uncertainties in emission, currency conversion, aggregation and international trade data. Besides, MRIO tables arrangement process is complex and consumes large amounts of time in order to collect and process the data (Andrew, Peters, \& Lennox, 2009; Lenzen, Wood, \& Wiedmann, 2010; Wilting, 2012).

This research employs high-resolution and highly detailed world input-output environmental accounts database with harmonized supply and symmetric inputoutput data-series, which are the main source of data for this study. MRIO data tables are high sector detailed covering 187 countries and 15,909 sectors with not interpolated or proxy-estimated time-series, which ensures a more significant, detailed, explicit and accurate data (Kanemoto, Moran, Lenzen, \& Geschke, 2014). Our study adds to the research gap in the literature proposing a new carbon estimation approach in clothing industry. Study reveals how increasing international trade and world trade liberalization for textile products influenced the EU embodied carbon emissions between 2000 and 2016. Globalization process lead to the removal of world trade quotas for textile and clothing goods, what led to the movement of production into developing countries (Los, Timmer, \& de Vries, 2014). The EU textile and clothing sector is a major example, affected by consumption and production fragmentation and its location changes implications on production and consumption system (Dunford, 2014; Dicken, 2011). We limit the scope of the analysis to the three major EU's textile import partners (China, India and Turkey), which compose around half of the total textile imports.

\section{Methodology}

Input-output methods have been widely applied to analyse environmental problems, relationships between sectors and embodied carbon in trade. As Peters \& Hertwich (2008) state, MRIO tables can be used in order to estimate economic inter-dependences among economic activities and carbon emissions.

The traditional input-output model can be described as the following equation:

$$
X^{*}=A^{*} X^{*}+Y^{*}
$$

and transforming the expression we get:

$$
X^{*}=\left(I-A^{*}\right)^{-1} Y^{*}
$$

where $\mathrm{X}$ represents the column vector of the total output of sector, A represents direct consumption coefficient matrix with data in intermediate use, $\mathrm{Y}$ denotes the column vector of final demand of sector. $\left(I-A^{*}\right)^{-1}$ is the Leontief inverse, which is total consumption coefficient. Analysing world multi-regional input-output method, direct carbon emission coefficient $\theta_{i}^{r}$ in a specific $i$ sector of specific $r$ country or region can be expressed as:

$$
\theta_{i}^{r}=\frac{P_{i}^{r}}{X_{i}^{r}}
$$


Where $\mathrm{P}$ represents direct $\mathrm{CO} 2$ emissions in sector $i$ of country or region $r$. $X$ represents the total output in sector $i$ of country or region $r$.

After combining direct $\mathrm{CO} 2$ emission coefficient with Leontief inverse matrix, the total $\mathrm{CO} 2$ emission coefficient can be expressed as:

$$
\lambda=\theta\left(-A^{*}\right)^{-1}
$$

By multiplying the trade volume $\mathrm{Y}$ in sector $i$ of country or region $r$ by total $\mathrm{CO} 2$ emission coefficient $\lambda$, carbon emissions in trade are calculated. From Eq. (5) and (6) we can obtain the carbon emissions through the exports or imports in sector $i$ of country or region $r$.

$$
\begin{aligned}
& \mathrm{CE}=\theta(I-\mathrm{A})^{-1} Y^{e x} \\
& \mathrm{CI}=\sum \theta^{*}\left(I-A^{*}\right)^{-1} Y^{i m}
\end{aligned}
$$

In our study we use data only for textiles and clothing sector with 2 regions - Europe and Asia region (China, Turkey and India), which are 30 countries in total.

\section{Results}

Globalization processes in clothing industry began to develop more rapidly after the removal of world trade quotas for textile and clothing products (Adhikari \& Yamamoto, 2007). This trade liberalization allowed moving the textile and clothing production into developing countries. Our study results show that in textile industry higher growth of EU CO2 imports quantities was observed just after the removal of world trade quotas for textile and clothing products in 2002 (Figure 1). Our results reveal that carbon emissions embodied in the EU textile and clothing imports growth was fastest from China, which were only 3032 kilotons of $\mathrm{CO} 2$ in 2002 (before the trade quotas removal) and just in three years grew up to 6877 kilotons of CO2 in 2005 and up to 8965 kilotons of CO2 in 2008.

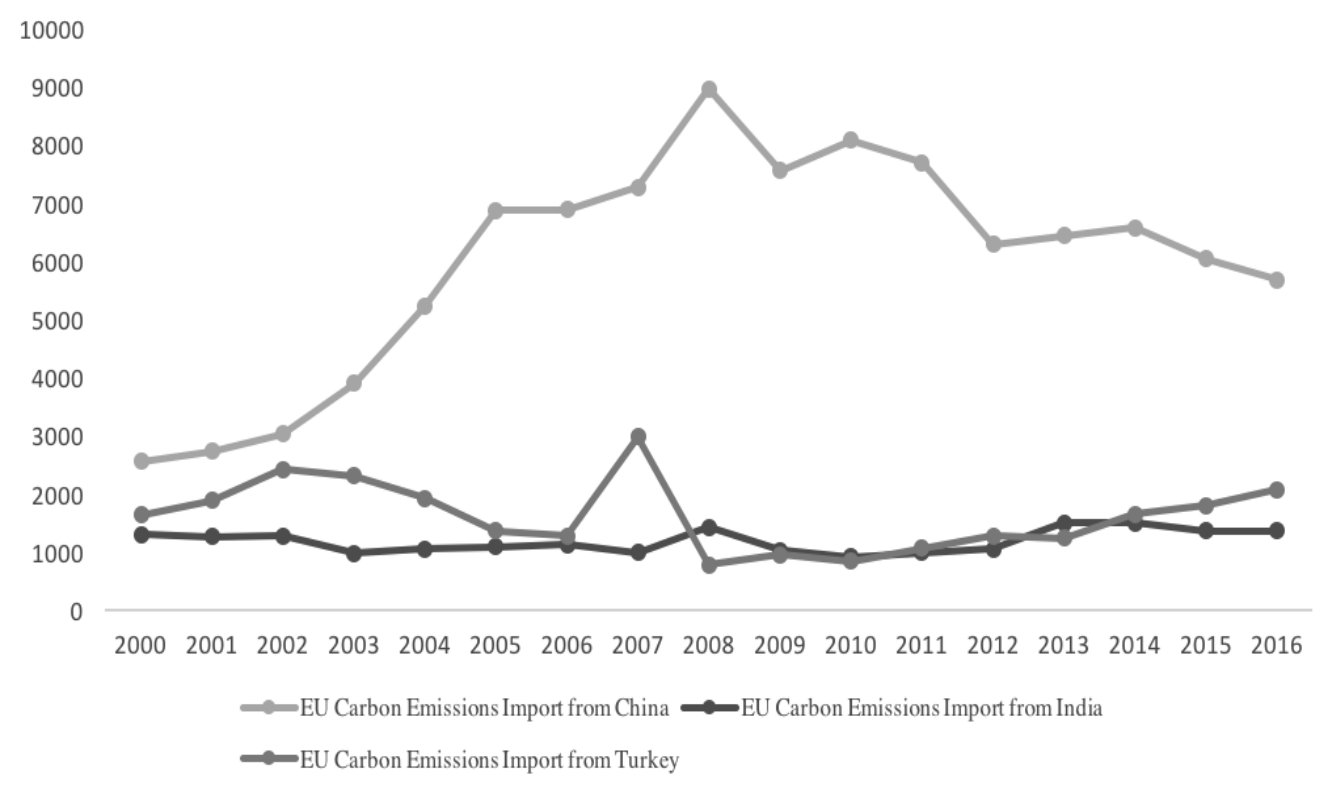

Figure 1. EU Import of $\mathrm{CO} 2$ in Textile and Clothing Industry from its Main Trade Partners, in 2000-2016. Unit: Kilotons

The peak of $\mathrm{CO} 2$ emissions in imports from China was reached in 2008 ( $8965 \mathrm{Kt}$ of $\mathrm{CO} 2)$, just before the financial crisis. After 2008, imports embodied emissions dropped and had a decreasing trend, partly due to the decrease in final consumption for textile goods after economic crisis and due to technology improvements in China. As is shown in Table 1 , embodied in the EU textile imports carbon emissions from China increased from 2000 to 2008 by $252 \%$. India and Turkey are among the main EU trade partners in textile sector, however as our calculations revealed, their amounts of embodied carbon emissions in exports were not very significant, when compared to China's.

Estimated embodied $\mathrm{CO} 2$ emissions in imports to each of the EU member state show that the largest embodied CO2 emissions imports contributors were United Kingdom and Germany, followed by Italy, France and Spain. As is shown in Figure 2, the growth rate of the EU embodied emissions between 2002 and 2005 was mainly driven by United Kingdom and Germany. In other words, the world trade quotas removal for textile goods in 2002 had very large impact on embodied in textile $\mathrm{CO} 2$ import growth and the largest amounts of this growth were due to the import of textile goods into United Kingdom and Germany. 


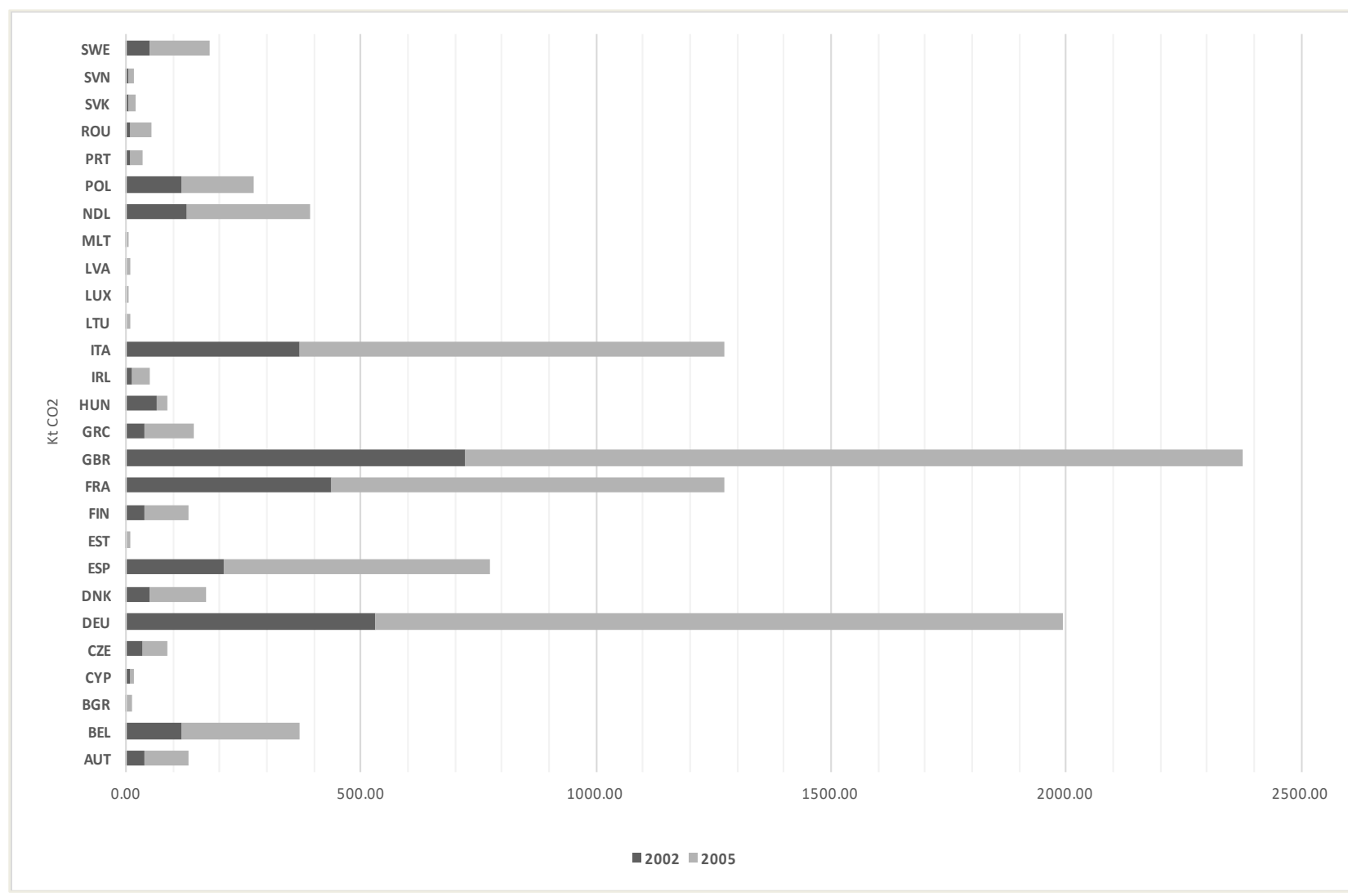

Figure 2. EU CO2 Imports from its Biggest Trade Partner - China, Changes by Country in 2002 and 2005. Unit: Kilotons

Study results show that in 2008 , when import of CO2 emissions achieved the peak of growth before the financial crisis, United Kingdom composed $22 \%$ and Germany $21 \%$ of the total CO2 imports in the EU textile sector (Figure 3). Therefore, just United Kingdom and Germany alone contributed to around $43 \%$ of total EU CO2 emissions embodied in imports from China, which is the largest EU imports partner in textile sector. France and Italy contributed $13 \%$ each, and Spain - $9 \%$ of the total EU embodied carbon emissions in 2008. United Kingdom, Germany, Italy, France and Spain are the main carbon emission contributors, which form around $78 \%$ of the total EU carbon emissions embodied in the textile imports. The rest of the European countries contributed around $22 \%$ of total carbon emissions embodied in the imports.

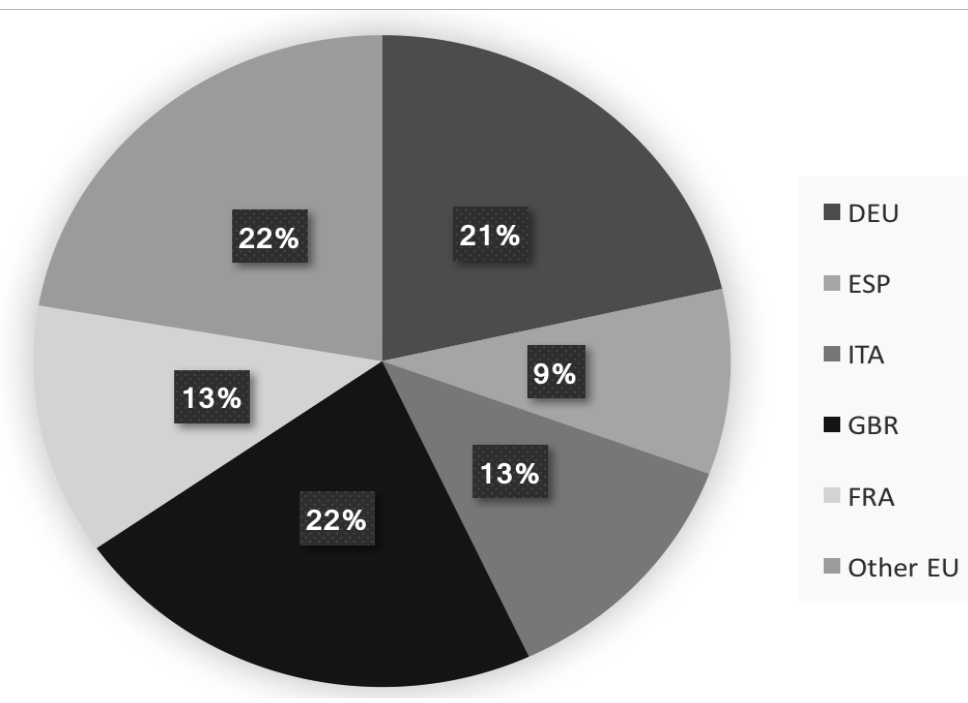

Figure 3. Break Down of Emissions Embodied in the EU textile and Clothing Sector Imports in 2008 from China, by EU Country. Unit: Kilotons 
In Figure 4 we can see that Germany's domestic CO2 emission decrease trend is similar to the $\mathrm{CO} 2$ emissions embodied in imports increase trend. This suggests that instead of reducing carbon emissions, Germany shifted the $\mathrm{CO} 2$ production outside. In 2016, CO2 emissions, produced by Germany's textile and clothing sector, composed 671 kilotons, while the imported emissions composed 2087 kilotons. Germany's carbon emissions in textile and clothing industry, calculated including the emissions embodied in imports, were $311 \%$ higher than calculated by traditional (territorial) method.

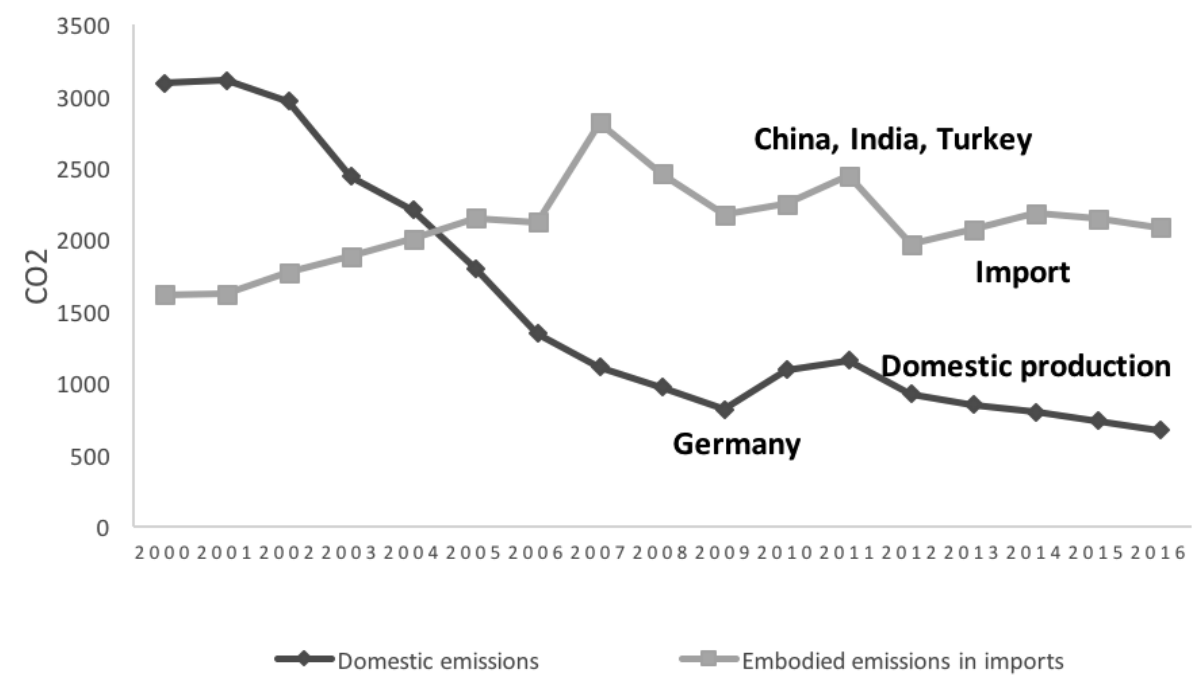

Figure 4. CO2 Emissions Produced in Germany's Textile and Clothing Sector and Transfers to Germany from China, India and Turkey, 2000-2016. Unit: Kilotons

Therefore, even if Germany officially achieved emission reductions in textile and clothing sector, its emissions embodied in imports from China, India and Turkey analysis shows, that $\mathrm{CO} 2$ production was just shifted abroad instead of being reduced. After world trade quotas removal for textile goods in 2002, up to 2007, when financial crisis started, Germany showed domestic emission reductions, which decreased from 2965 to 1111 kilotons of
CO2 (166\% decrease). At the same time, carbon emissions embodied in imports from China, India and Turkey increased from 1773 to 2815 kilotons of CO2, in 2002 and 2007, accordingly (58 \% increase). Germany's carbon emissions, including emissions embodied in imports, composed 2758 kilotons of $\mathrm{CO} 2$ in 2016 , from which $75 \%$ were emissions embodied in imports (Figure 5).

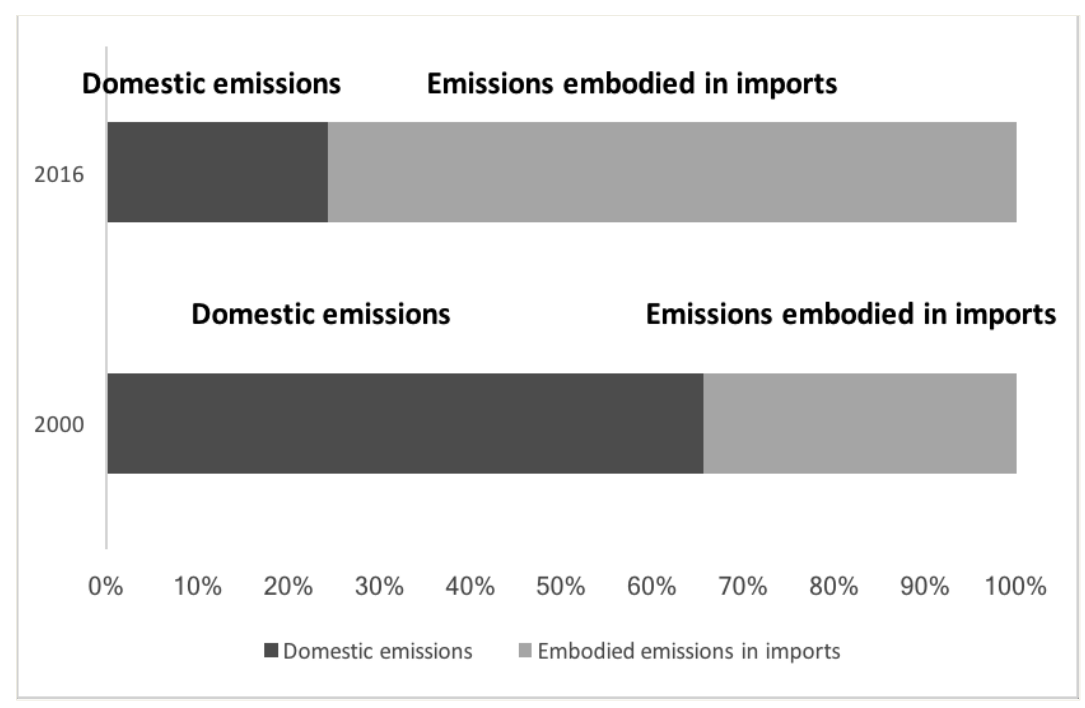

Figure 5. Domestic CO2 Emissions Versus the Imported Emissions in the Textile and Clothing Sector of Germany, 2000 and 2016. Unit: Kilotons

As a result, domestic carbon emissions have decreased, while emissions abroad have increased. This paper only estimates emissions embodied in the imports from the EU top trade partners - China, India and Turkey. We estimate 
Ignas Valodka, Vytautas Snieska, Antonio Mihi-Ramirez. Impact of the International Trade on the EU Clothing Industry...

that the inclusion of the all emissions from the rest of the world into Germany's textile sector, would expose more than twice bigger amounts of $\mathrm{CO} 2$. Indeed, while Germany's domestic carbon emissions in textile and clothing sector decreased, its import related emissions from its main trade partners increased by $29 \%$ in the analysed period between 2000 and 2016. Table 1 represents CO2 emissions embodied in the EU textile and clothing goods imports from China, India and Turkey in 2002, 2005, 2008 and 2016.

Table 1

CO2 Emissions Embodied in the EU Textile and Clothing Product Imports from China, India and Turkey in 2002, 2005, 2008 and 2016 (Kt CO2)

\begin{tabular}{|c|c|c|c|c|c|c|c|c|c|c|c|c|}
\hline & \multicolumn{3}{|c|}{2002} & \multicolumn{3}{|c|}{2005} & \multicolumn{3}{|c|}{2008} & \multicolumn{3}{|c|}{2016} \\
\hline & CHN & IND & TUR & CHN & IND & TUR & CHN & IND & TUR & CHN & IND & TUR \\
\hline$A U T$ & 41 & 12 & 40 & 94 & 12 & 18 & 104 & 15 & 13 & 64 & 19 & 30 \\
\hline$B E L$ & 117 & 27 & 55 & 251 & 25 & 23 & 311 & 31 & 12 & 128 & 14 & 23 \\
\hline$B G R$ & 2 & 0 & 4 & 11 & 0 & 4 & 13 & 1 & 6 & 5 & 0 & 40 \\
\hline$C Y P$ & 9 & 2 & 2 & 10 & 1 & 2 & 11 & 1 & 1 & 5 & 1 & 0 \\
\hline$C Z E$ & 37 & 3 & 4 & 51 & 2 & 4 & 65 & 2 & 3 & 22 & 3 & 7 \\
\hline$D E U$ & 532 & 261 & 979 & 1462 & 210 & 480 & 1922 & 290 & 249 & 1022 & 290 & 581 \\
\hline$D N K$ & 52 & 20 & 40 & 117 & 23 & 27 & 154 & 31 & 16 & 77 & 26 & 40 \\
\hline$E S P$ & 209 & 70 & 59 & 564 & 100 & 75 & 823 & 129 & 71 & 516 & 119 & 271 \\
\hline$E S T$ & 2 & 0 & 1 & 8 & 1 & 1 & 10 & 0 & 7 & 9 & 4 & 12 \\
\hline FIN & 41 & 12 & 13 & 92 & 15 & 9 & 123 & 16 & 4 & 50 & 8 & 9 \\
\hline FRA & 436 & 213 & 275 & 835 & 148 & 113 & 1117 & 198 & 65 & 565 & 154 & 106 \\
\hline$G B R$ & 723 & 362 & 596 & 1651 & 312 & 350 & 1990 & 383 & 159 & 1637 & 413 & 441 \\
\hline$G R C$ & 40 & 12 & 32 & 107 & 14 & 31 & 149 & 15 & 20 & 115 & 16 & 53 \\
\hline$H U N$ & 66 & 6 & 5 & 22 & 2 & 3 & 18 & 2 & 3 & 7 & 2 & 5 \\
\hline$I R L$ & 15 & 14 & 10 & 37 & 9 & 6 & 65 & 9 & 4 & 38 & 12 & 9 \\
\hline ITA & 370 & 139 & 104 & 903 & 127 & 85 & 1116 & 158 & 62 & 594 & 108 & 131 \\
\hline$L T U$ & 2 & 1 & 2 & 8 & 1 & 3 & 17 & 1 & 2 & 13 & 2 & 11 \\
\hline$L U X$ & 2 & 0 & 0 & 3 & 0 & 0 & 4 & 0 & 0 & 6 & 0 & 1 \\
\hline$L V A$ & 3 & 0 & 1 & 7 & 0 & 1 & 13 & 1 & 1 & 9 & 1 & 10 \\
\hline$M L T$ & 3 & 1 & 1 & 3 & 0 & 1 & 7 & 0 & 0 & 5 & 0 & 0 \\
\hline$N D L$ & 130 & 60 & 114 & 263 & 37 & 66 & 363 & 50 & 32 & 339 & 54 & 96 \\
\hline$P O L$ & 117 & 10 & 39 & 155 & 12 & 22 & 269 & 26 & 17 & 266 & 50 & 108 \\
\hline$P R T$ & 10 & 10 & 2 & 24 & 11 & 1 & 45 & 15 & 1 & 34 & 15 & 3 \\
\hline$R O U$ & 8 & 0 & 2 & 46 & 0 & 3 & 39 & 1 & 7 & 15 & 1 & 16 \\
\hline$S V K$ & 7 & 2 & 2 & 14 & 4 & 2 & 31 & 6 & 3 & 18 & 12 & 14 \\
\hline$S V N$ & 5 & 1 & 3 & 12 & 1 & 2 & 28 & 2 & 2 & 40 & 2 & 4 \\
\hline SWE & 52 & 30 & 29 & 127 & 23 & 26 & 156 & 30 & 13 & 127 & 31 & 40 \\
\hline Total ES: & 3032 & 1269 & 2415 & 6878 & 1089 & 1355 & 8965 & 1416 & 772 & 5678 & 1359 & 2063 \\
\hline
\end{tabular}

Table 2 represents emissions coefficients in kilotons of $\mathrm{CO} 2$ per million of dollars of textile and clothing products for Germany, as well, as China, India and Turkey. Germany's carbon emission coefficients, comparing to its trade partners, in most of the analysed period, are the lowest.

Germany's import related carbon emissions from China, India and Turkey have higher emissions coefficients than domestic production. China showed highest emission coefficients, while, at the same time, it is the largest import partner of Germany. China's carbon emission coefficient in textile and clothing sector has improved from 0.45 in 2000 to 0.17 in 2015 , what mainly contributed to EU's embodied emissions decrease after 2008 (Figure 1). Germany's carbon emission coefficient has dropped from 0.22 in 2000 to 0.043 in 2015. Comparing China's and Germany's emission coefficients we can see that even if China has improved its production efficiency, comparing to Germany, it still requires 4 times more carbon emissions to produce one unit of output of textile and clothing goods. For Germany choosing the right import partner or producing locally might help reducing $\mathrm{CO} 2$ emissions in the sector.

Table 2

Carbon Emission Coefficients in Textile and Clothing Sector of Germany and its Main Import Partners

\begin{tabular}{l|ccccc} 
& $\mathbf{2 0 0 0}$ & $\mathbf{2 0 0 5}$ & $\mathbf{2 0 1 0}$ & $\mathbf{2 0 1 5}$ \\
\hline DEU & 0.22 & 0.12 & 0.07 & 0.04 & 0.17 \\
CHN & 0.45 & 0.34 & 0.23 & 0.15 & 0.20 \\
IND & 0.38 & 0.19 & 0.08 & 0.14 \\
TUR & 0.18 & 0.12 & & \\
\hline
\end{tabular}

\section{Conclusions}

1. Our results show the increase of emissions embodied in the European clothing industry imports, especially after the world trade quotas for textile goods removal in 2002. From 2002 up to economic crisis in 2008 embodied emissions in imports has increased three times, from 3032 kilotons to 8964 kilotons of $\mathrm{CO} 2$ emissions.

2. Financial crisis of 2008 has reduced the quantity of embodied in the EU imports $\mathrm{CO} 2$ emissions, together with the reduction of the EU textile import and consumption. Our study results show that significant amounts of $\mathrm{CO} 2$ 
emissions in the EU textile and clothing sector were outsourced abroad, causing carbon leakage problem.

3. The estimation of the carbon emissions embodied in textile imports for each EU country allowed determining that United Kingdom and Germany had the largest impact on the EU CO2 emission embodied in imports, together creating the $43 \%$ of the total CO2 import in 2008. Our results also show that the major drivers of embodied $\mathrm{CO} 2$ emissions growth were the trade quotas for textile products removal in 2002 and therefore the increased consumption for textile products, imported from China into the EU (mostly into the UK and Germany).

4. The study also revealed that between 2000 and 2016 Germany's domestic CO2 emissions have declined over time. However our results suggest that the reduced domestic emissions were simply replaced by imported ones, thus causing overall global carbon increase. This is the indication of the issues in current environmental regulatory policies. As the study's results show, Germany's embodied carbon emissions in imports were more than 3 times higher than its domestic carbon emissions in 2016.

5. The assessment of the carbon emission coefficients revealed, that between 2000 and 2016 China had the highest and Germany the lowest carbon emission coefficients. This might indicate the direction of future EU environmental policy improvement direction, as the major part of Germany's CO2 emissions come from China. Namely, the improvements of China's carbon emission coefficients by means of the stricter ecological requirements by the EU to the technology, applied in the textile sector of the main exporting textile to the EU partners.

\section{References}

Adhikari, R., \& Yamamoto, Y. (2007). The textile and clothing industry: Adjusting to the post-quota world, industrial development for the 21st century: Sustainable Development Perspectives. United Nations. Department of Economic and Social Affairs, New York, p. 432.

Afionis, S., Sakai, M., Scott, K., Barrett, \& J., Gouldson, A. (2017). Consumption-based carbon accounting: does it have a future? WIREs Climate Change, 8, e438. https://doi.org/10.1002/wcc.438

Ali, Y. (2017). Carbon, water and land use accounting: Consumption vs production perspectives. Renewable \& Sustainable Energy Reviews, 67, 921-934.https://doi.org/10.1016/j.rser.2016.09.022

Andrew, R., Peters, G. P., \& Lennox, J. (2009). Approximation and regional aggregation in multi-regional input-output analysis for national carbon footprint accounting. Economic System Research, 21, 311-335. https://doi.org/10.1080/ 09535310903541751

Andrew, R. M., Davis, S. J., \& Peters, G. (2013). Climate policy and dependence on traded carbon. Environmental Research Letter, 8, 034011. https://doi.org/10.1088/1748-9326/8/3/034011

Caldeira, K., \& Davis, S. J. (2011). Accounting for carbon dioxide emissions: a matter of time. Proceedings of the National Academy of Sciences of the United States of America, 108, 8533-8534. https://doi.org/10.1073/pnas.1106517108

Corrado, S., Rydberg, T., Oliveira, F., Cerutti, A., \& Sala, S. (2020). Out of sight out of mind? A life cycle-based environmental assessment of goods traded by the European Union. Journal of Cleaner Production, 246. https://doi.org/10.1016/j.jclepro.2019.118954

Davis, S. J., Peters, G. P., \& Caldeira, K. (2011). The supply chain of CO2 emissions. Proceedings of the National Academy of Sciences, 108, 18554-18559. https://doi.org/10.1073/pnas.1107409108

Davis, S. J., \& Caldeira, K. (2010). Consumption-based accounting of CO2 emissions. Proceedings of the National Academy of Sciences of the United States of America, 107, 5687-5692. https://doi.org/10.1073/pnas.0906974107

Dicken, P. (2011). 'Fabricating fashion': the clothing industries. In: Dicken, P. (Ed.), Global Shift: Mapping the Changing Contours of the World Economy, sixth ed. Sage Publications, pp. 302e330.

Duan, Y. W., \& Jiang, X. M. (2018). Visualizing the change of embodied CO2 emissions along global production chains. Journal of Cleaner Production, 194, 499-514. https://doi.org/10.1016/j.jclepro.2018.05.133

Dunford, M. (2004). The changing profile and map of the EU textile and clothing industry. In: Faust, M., Voskamp, U., Wittke, V. (Eds.), European Industrial Restructuring in a Global Economy: Fragmentation and Relocation of Value Chains. SOFI.

EC (2016). Communication from the Commission to the European Parliament, the Council, the European Economic and Social Committee and the Committee of the Regions. Next Steps for a Sustainable European Future European Action for Sustainability. COM, p. 739, 2016.

Feng, K., Davis, S. J., Sun, L., Li, X., Guan, D., Liu, W., Liu, Z., \& Hubacek, K. (2013). Outsourcing CO2 within China. Proceedings of the National Academy of Sciences of the United States of America, 110, 11654-11659. https://doi.org/10.1073/pnas.1219918110 
Ignas Valodka, Vytautas Snieska, Antonio Mihi-Ramirez. Impact of the International Trade on the EU Clothing Industry...

Fernandez-Amador, O., Francois, J.F., Oberdabernig, D.A., \& Tomberger, P. (2017). Carbon dioxide emissions and economic growth: an assessment based on production and consumption emission inventories. Ecological Economics, 135, 269-279. https://doi.org/10.1016/j.ecolecon.2017.01.004

Fezzigna, P., Borghesi, S., \& Caro, D. (2019). Revising Emission Responsibilities through Consumption-Based Accounting: A European and Post-Brexit Perspective. Sustainability, 11(2). https://doi.org/10.3390/su11020488

Hamilton, H. A., Ivanova, D., Stadler, K., Merciai, S., Schmidt, J., van Zelm, R., Moran, D., \& Wood, R. (2018). Trade and the role of non-food commodities for global eutrophication. Nature, Sustainability 1, 314e321. https://doi.org/10. 1038/s41893-018-0079-z

Hertwich, E. G., \& Peters, G. P. (2009). Carbon footprint of nations: a global, trade-linked analysis. Environmental Science \& Technology 43 (16) 6414-6420. https://doi.org/10.1021/es803496a

IPCC (2018). Global Warming of $1.5^{\circ} \mathrm{C}$. An IPCC Special Report on the impacts of global warming of $1.5^{\circ} \mathrm{C}$ above preindustrial levels and related global greenhouse gas emission pathways, in the context of strengthening the global response to the threat of climate change, sustainable development, and efforts to eradicate poverty [Masson-Delmotte, V., P. Zhai, H.-O. Portner, D. Roberts, J. Skea, ... T. Waterfield (eds.)]. In Press. 2019 Intergovernmental Panel on Climate Change. World Meteorological Organization, Geneva, Switzerland.

Jackson, T., (2011). Societal transformations for a sustainable economy. Natural Resources Forum 35, $155 \mathrm{e} 164$. https://doi.org/10.1111/j.1477-8947.2011.01395.x

Kanemoto, K., Moran, D., Lenzen, M., \& Geschke, A. (2014). International trade undermines national emission reduction targets: new evidence from air pollution. Global Environmental Change, 24, 52e59. https://doi.org/10.1016/j. gloenvcha.2013.09.008

Leggett, J. A. (2011). China's greenhouse gas emissions and mitigation policies. Congressional Research Service, Washington DC.

Lenzen, M., Moran, D., Kanemoto, K., Foran, B., Lobefaro, L., \& Geschke, A. (2012). International trade drives biodiversity threats in developing nations. Nature, 486, 109e112. https://doi.org/10.1038/nature11145

Lenzen, M., Pade, L. L., \& Munksgaard, J. (2004). CO2 multipliers in multi-region input-output models. Economic Systems Research, 16 (4), 391-412. https://doi.org/10.1080/0953531042000304272

Lenzen, M., Wood, R., \& Wiedmann, T. (2010). Uncertainty analysis for multi-region input- output models-a case study of the UK's carbon footprint. Economic System Research, 22, 43-63. https://doi.org/10.1080/09535311003661226

Liu, L. (2015). A critical examination of the consumption-based accounting approach: Has the blaming of consumers gone too far? WIREs Climate Change, 6, 1-8. https://doi.org/10.1002/wcc.325

Los, B., Timmer, M. P., \& de Vries, G.J. (2014). How global are global value chains?A new approach to measure international fragmentation. Journal of regional Science, 1, 66e92. https://doi.org/10.1111/jors.12121

Munksgaard, J., Minx, J., Christofferson, L., Pade, L.-L., \& Suh, S. (2007). Models for national CO2 accounting. In: Suh, S. (Ed.), Handbook on Input-Output Economics for Industrial Ecology. Springer, Dordrecht, The Netherlands.

Nakano, S., Okamura, A., Sakurai, N., Suzuki, M., Tojo, T., \& Yamano, N. (2009). The measurement of CO2 embodiments in international trade: Evidence from the harmonised input-output and bilateral trade database. In: OECD (Eds.), Directorate for Science, Technology, and Industry. OECD, Paris.

Peters G. P., \& Hertwich E. G. (2008). CO2 embodied in international trade with implications for global climate policy. Environmental Science \& Technology, 2008; 42(5), 1401-7. https://doi.org/10.1021/es072023k

Peters, G. P. (2008). From production-based to consumption-based national emission inventories. Ecological Economics, 65(1), 13-23.s's: https://doi.org/10.1016/j.ecolecon.2007.10.014

Peters, G. P., \& Hertwich, E. G. (2008), 'Post-Kyoto greenhouse gas inventories: Production versus consumption. Climatic Change, 86, 51-66. https://doi.org/10.1007/s10584-007-9280-1

Peters, G. P., Marland, G., Le Quere, C., Boden, T., Canadell, J. G., \& Raupach, M. R. (2011). Rapid growth in CO2 emissions after the 2008-2009 global financial crisis. Nature Climate Change 2. https://doi.org/10.1038/nclimate1332

Simas, M., Golsteijn, L., Huijbregts, M., Wood, R., \& Hertwich, E. (2014). The "bad labor" footprint: quantifying the social impacts of globalization. Sustainability 6, 7514e7540. https://doi.org/10.3390/su6117514

Steininger, K.W., Lininger, C., Meyer, L.H., Munoz, P., \& Schinko, T. (2015). Multiple carbon accounting to support just and effective climate policies. National Climate Change, 6, 35-41. https://doi.org/10.1038/nclimate2867 
Su, B., \& Ang, B. W. (2014). Input-output analysis of CO2 emissions embodied in trade: A multi-region model for China. Applied Energy, 114, 377-384. https://doi.org/10.1016/j.apenergy.2013.09.036

Sun, X.D., Li, J.S., Qiao, H., \& Zhang, B. (2017). Energy implications of China's regional development: New insights from multi-regional input-output analysis. Applied Energy 196, 118-131. https://doi.org/10.1016/j.apenergy.2016.12.088

Tukker, A., Huppes, G., Guinee, J., Heijungs, R., d. Koning, A., v. Oers, L., ...Nielsen, P. (2006). Environmental impact of products (EIPRO): Analysis of the life cycle environmental impacts related to the final consumption of the EU-25. Retrieved from ec.europa.eu/environment/ipp/identifying.htm

UN, (2015). Sustainable Development Goals. https://sustainabledevelopment.un.org/. (Accessed September (2018).

Wiedmann, T. (2009). A review of recent multi-region input-output models used for consumption-based emission and resource accounting. Ecological Economics, 69, 211-222. https://doi.org/10.1016/j.ecolecon.2009.08.026

Wiedmann, T., Wood, R., Lenzen, M., Minx, J., Guan, D., \& Barrett, J. (2008). Development of an embedded carbon emissions indicator-producing a time series of input-output tables and embedded carbon dioxide emissions for the UK by using a MRIO data optimisation system (EV02033). Defra, London.

Wilting, H., \& Vringer, K. (2007). Environmental accounting from a producer or a consumer principle: An empirical examination covering the world. 16th International Input-Output Conference. Istanbul, Turkey. Conference proceedings (2-6 July, 2007) available at http://www.iioa.at/Conference/ 16th-downable\%20paper.html.

Wilting, H. C. (2012). Sensitivity and uncertainty analysis in MRIO modeling; some empirical results with regard to the Dutch carbon footprint. Economic System Research, 24, 141-171. https://doi.org/10.1080/09535314.2011.628302

Wood, R., Stadler, K., Simas, M., Bulavskaya, T., Giljum, S., Lutter, S., \& Tukker, A. (2018). Growth in environmental footprints and environmental impacts embodied in trade: Resource efficiency indicators from EXIOBASE3. Journal of Industrial Ecology, 22, 553e564. https://doi.org/10.1111/jiec.12735

Xu, X. L., Mu, M. J., \& Wang, Q. (2017). Recalculating CO2 emissions from the perspective of value-added trade: An input-output analysis of China's trade data. Energy Policy, 107, 158-166. https://doi.org/10.1016/j.enpol.2017.04.026

Xu, Y., \& Dietzenbacher, E. (2014). A structural decomposition analysis of the emissions embodied in trade. Ecological Economics 101, 10e20. https://doi.org/10.1016/j.ecolecon.2014.02.015

Zhong, Z. Q., Jiang, L., \& Zhou, P. (2018). Transnational transfer of carbon emissions embodied in trade: Characteristics and determinants from a spatial perspective. Energy, 147, 858-875. https://doi.org/10.1016/j.energy.2018.01.008

Zhu, Y., Shi, Y., Wu, J., Wu, L., \& Xiong, W. (2018). Exploring the characteristics of CO2 emissions embodied in international trade and the fair share of responsibility. Ecological Economics, 146, 574-587. https://doi.org/10. 1016/j.ecolecon.2017.12.020

The article has been reviewed.

Received in January 2020; accepted in June 2020. 